\title{
ARTICLE \\ Characterization of amylase and protease activity in the digestive tract of two teleosts (Labeo rohita and Anabas testudineus) with different feeding habits
}

\author{
Sanjeet Debnath, Surjya Kumar Saikia* \\ Aquatic Ecology and Fish Biology Laboratory, Department of Zoology, Visva-Bharati, Santiniketan, West Bengal, India
}

\begin{abstract}
Two teleosts (Rohu, Labeo rohita and Koi, Anabas testudineus), both with contrasting feeding habits (herbivorous versus carnivorous) were studied for amylase and protease activity concerning different regions of their digestive tracts. Significant differences in enzymatic activity across different regions of the digestive tracts were observed. Rohu, with three equal regions of the stomachless gut, showed the highest amylolytic activity at the posterior digestive tract but the highest proteolytic activity is limited to mid region. Contrary to such observation, Koi with three distinct regions of the digestive tract (stomach, pyloric caeca and intestine), the pyloric caeca exhibited the highest specific activity for both amylase and total protease. The optimum $\mathrm{pH}$ and temperature conditions were determined concerning the activity for both amylase and protease.

Acta Biol Szeged 64(2):173-179 (2020)
\end{abstract}

\author{
KEY WORDS \\ a-amylase \\ digestive enzyme \\ digestive tract \\ Rohu \\ Koi \\ protease \\ ARTICLE INFORMATION \\ Submitted \\ 11 June 2020 . \\ Accepted \\ 04 October 2020 \\ *Corresponding author \\ E-mail: surjyasurjya@gmail.com
}

\section{Introduction}

Like other vertebrates, the activity of digestive enzymes in fish is influenced by the abiotic factors, such as temperature (Kuz'mina 1996), particular timing of day (Kuz'mina and Strelnikova 2008) and different seasons (Kofuji et al. 2005), and biotic factors, including the preference of food (Ugolev and Kuz'mina 1993), the age of the organism (Kuz'mina 1996), state of infestation with parasites (Izvekova and Solovyev 2012), etc. Hence, careful investigation of the pattern of the digestive activity of different enzyme would provide not only the complete information of the digestive physiology of fish, but also the age, health and feeding ecology of the organism. The $\alpha$-amylase and protease were one of the major digestive enzymes found in digestive tract (DT) of fish, which are widely studied for the above purpose.

In India and rest of South-East Asia, Rohu (Labeo rohita) has been the most preferred cultivable fish over many other freshwater species and extensively cultivated in India, Nepal, Bangladesh, Myanmar, Sri Lanka and Pakistan (Talwar and Jhingran 1991). This Indian Major Carp (Rohu), has always been receiving special attention as a potential animal crop over centuries for alleviating malnutrition in human populations because of its capabil- ity to retain high amounts of vitamins and other micronutrients at a reasonable cost (Mohanty et al. 2016). On the other hand, the cultivation of climbing perch (Anabas testudineus), locally known as Koi, is gaining importance as one of the most potential candidates for aquaculture because of its high market demand and greater consumer preference throughout all the seasons (Uddin et al. 2016). It is a good source of protein, fat, vitamins, amino acids and fatty acids (Bogard et al. 2015; Paul et al. 2017). Being an air-breathing fish, Koi is also a model of interest for several scientific studies for its low maintenance effort, as well as easy availability and hardy nature (e.g., Munshi et al. 2018). Wide spreading aquaculture of Koi has been a great demand among the entire Indian sub-continent including Bangladesh, Myanmar, and Indonesia.

Voluminous research works have been carried out on the growth and feeding biology of Indian Major Carps (see review Majumder and Saikia 2020). But, except few (e.g., Mandal and Ghosh 2010; Singh et al. 2018), these studies have not addressed the details of the digestive physiology, particularly the activity of the crucial digestive enzymes along the digestive tract. These studies considered the whole intestine as an overall source of activity of a particular enzyme. As a result the specific region wise performance of an enzyme remains shadowed. Similarly, studies on Koi with regard to the effects 
of toxicants on the digestive system were performed (Samanta et al. 2014; Kole et al. 2017). Banerjee and Ray (2018) reported the seasonal variation in the activity of digestive enzymes of Koi. However, these studies are not elaborate since these studies treated whole gut as site of activity of a particular enzyme. Of late, more precise explanation of digestive enzyme activity across the gut length of fish has been started (e.g., Weinrauch et al. 2019). More precise observation of the process of the activity of digestive enzymes will provide supportive information to improvise diet formulations for optimum supplementary feeding. In the present study, an attempt has been made to characterize region wise enzyme activities keeping in mind the optimum $\mathrm{pH}$ and temperature. This study establishes the optimum $\mathrm{pH}$ and temperature for amylase and protease activity in the tissue extracts of digestive tract from Rohu and Koi. The feeding habits of both the fishes were compared keeping in view of the activity of enzymes across different regions of digestive tract.

\section{Material and methods}

\section{Experimental animals}

A total of 20 fish were collected from local fish pond $\left(23^{\circ} 37^{\prime} \mathrm{N}, 8^{\circ} 49^{\prime} \mathrm{E}\right)$ during February, 2020 using gill net (08:00-09:00) and brought alive to the laboratory. In laboratory fishes were kept unfed in glass aquaria ( $45 \times 30$ $\mathrm{x} 30 \mathrm{~cm}, 30 \mathrm{~L}$ ) for 24 hours before analysis. Throughout the experiment, the water temperature was $28.67 \pm 1.87$ ${ }^{\circ} \mathrm{C}$; dissolved oxygen $7.61 \pm 0.26 \mathrm{mg} / \mathrm{L}$; pH $7.48 \pm 0.21$; conductivity $623 \pm 15.2 \mu \mathrm{S}$; photoperiod 12 :12 (light hour : dark hour).

\section{Preparation of extracts}

On the second day of collection, a small amount of food was introduced to stimulate the digestive function in the two fish species. After one hour, fish were euthanized with the help of ice-cold water and dissected on ice board. The DT was dissected out from esophagus to anus, washed in chilled distilled water and blotted with paper towel. For Rohu, the DT was divided lengthwise into three equal segments viz. anterior, middle and posterior starting from the esophagus to anus. Like Rohu, the short DT of Koi was also divided into three parts based on the morphological difference and identified as the stomach, pyloric caeca and intestine. Tissues were initially stored in $-40^{\circ} \mathrm{C}$ until use. Later, $10 \%$ tissue homogenate were prepared at $4{ }^{\circ} \mathrm{C}$ in a buffer containing $100 \mathrm{mM}$ Tris- $\mathrm{HCl}, \mathrm{pH}$ 7.4, centrifuged at $10000 \mathrm{~g}$ at $4{ }^{\circ} \mathrm{C}$ for $10 \mathrm{~min}$, and the supernatants (or the DT extracts) were collected carefully.
Table 1. Activity of amylase and protease in different sections of the digestive tract of $L$. rohita $(n=10)$. Values are expressed as mean \pm SE. Means with different alphabets within a group show statistically significant difference at $\mathrm{p}<0.05$.

\begin{tabular}{llc}
\hline Digestive tract (DT) & \multicolumn{2}{c}{ Specific activity (U/mg protein) } \\
\cline { 2 - 3 } & Amylase & Total protease \\
\hline Anterior DT & $0.400 \pm 0.005^{\mathrm{a}}$ & $0.316 \pm 0.005^{\mathrm{c}}$ \\
Mid DT & $0.246 \pm 0.004^{\mathrm{b}}$ & $0.523 \pm 0.016^{\mathrm{a}}$ \\
Posterior DT & $0.182 \pm 0.022^{\mathrm{c}}$ & $0.483 \pm 0.012^{\mathrm{b}}$ \\
\hline
\end{tabular}

\section{Estimation of digestive enzymes}

\section{Amylase}

The activity of amylase was measured following the method of Bernfeld (1955) using potato-starch as the substrate. The specific activity was expressed as the measure of unit activity per $\mu \mathrm{g}$ protein, where one-unit activity was the amount of enzyme required to liberate $1 \mu \mathrm{g}$ of maltose per hour form the assay mixture.

\section{Protease}

Casein was used as substrate to measure the activity of protease according to Walter (1984). One unit of enzyme activity in each sample was expressed as the amount of enzyme required to liberate $1 \mu \mathrm{g}$ of tyrosine in one hour per $\mu \mathrm{g}$ protein. Method suggested by Lowry et al. (1951) was followed to estimate the amount of total protein in the DT extracts.

\section{Optimal range of $\mathrm{pH}$ and temperature}

Firstly, the individual optimum $\mathrm{pH}$ for each type of enzyme from different region of DT was determined spectrophotometrically using a range of buffer solutions (pH 1.0 to 10.0) as the assay medium. The buffers used were as follows: $0.2 \mathrm{M} \mathrm{KCl}-\mathrm{HCl}$ buffer ( $\mathrm{pH} 1.0$ and 2.0), $0.2 \mathrm{M}$ glycine- $\mathrm{HCl}$ buffer ( $\mathrm{pH} 3.0$ ), $0.1 \mathrm{M}$ citrate buffer (pH 4.0, 5.0, 6.0), 0.2 M Tris-HCl buffer ( $\mathrm{pH} 7.0,8.0,9.0$ ), $0.2 \mathrm{M}$ glycine- $\mathrm{NaOH}$ (pH 10.0), respectively. Finally, the optimal temperatures for the same digestive enzymes were determined by measuring their activity at several temperatures starting from $20{ }^{\circ} \mathrm{C}$ to $45{ }^{\circ} \mathrm{C}$ with $5{ }^{\circ} \mathrm{C}$ interval where, the $\mathrm{pH}$ condition was kept constant to the previously determined optimum level. The spectrophotometric enzyme activity assays were performed in triplicate.

\section{Data analysis}

Data from the replicates for digestive enzymes were combined for statistical analysis. One-way ANOVA was performed and multiple comparisons between mean values were made using Tukey's post hoc test. The alpha level 
was maintained less than 0.05 for all statistical analysis. Results are reported as mean values with SD. Minitab 18 was used for all statistical analysis.

\section{Results}

\section{Measurement and distribution of digestive enzymes}

The activity of amylase and protease from different parts of DT in Rohu is summarized in Table 1. Amylase activity in the anterior DT was much higher than the rest. The mid DT showed significantly less amylolytic activity than the anterior part $(\mathrm{p}<0.05)$ but, had higher activity when compared to the posterior region. On the other hand, in the mid DT, the protease activity was much higher than that in other parts. Levels of protease activity were in descending order in the DT were as follows: mid DT, posterior DT, and anterior DT. The distribution of the activity of amylase and protease in different digestive locations throughout the DT in Koi are summarized in Table 2. The pyloric caeca showed the maximum amylase activity followed by the intestine and stomach. Also, for proteolytic activity, pyloric caeca showed the dominant portion of the DT. There are no significant $(\mathrm{p}<0.05)$ difference between the total digestive protease activity in stomach and intestine.

\section{Characteristics of amylase and protease}

The results showed that the optimum $\mathrm{pH}$ value for amylase activity was 8.0 in both the anterior and mid DT in Rohu (Fig. 1a). On the other hand, the last segment of the DT showed an optimum $\mathrm{pH}$ of 7.0 for the amylolytic activity. The optimal temperature for amylase activity was $35^{\circ} \mathrm{C}$ throughout the DT (Fig. 1b).

Proteolytic enzyme showed optimum activity at $\mathrm{pH}$ 8.0 in both anterior and middle region of the DT in Rohu (Fig. 1c). However, the posterior region of the DT showed the highest proteolytic activity at $\mathrm{pH}$ 7. The optimum temperature for proteases, found in the DT of Rohu, to achieve the maximum activity was $35^{\circ} \mathrm{C}$ (Fig. 1d)

In Koi, the optimum $\mathrm{pH}$ value, at which the amylase

Table 2. Activity of amylase and protease in different sections of the digestive tract of $A$. testudineus $(n=10)$. Values are expressed as mean \pm SD. Means with different alphabets within a group show statistically significant difference at $p<0.05$.

\begin{tabular}{lll}
\hline Digestive tract (DT) & \multicolumn{2}{c}{ Specific activity (U/mg protein) } \\
\cline { 2 - 3 } & Amylase & Total protease \\
\hline Stomach & $0.099 \pm 0.014^{\mathrm{b}}$ & $0.285 \pm 0.004^{\mathrm{b}}$ \\
Pyloric caeca & $0.175 \pm 0.004^{\mathrm{a}}$ & $0.308 \pm 0.001^{\mathrm{a}}$ \\
Intestine & $0.113 \pm 0.002^{\mathrm{c}}$ & $0.281 \pm 0.001^{\mathrm{b}}$ \\
\hline
\end{tabular}
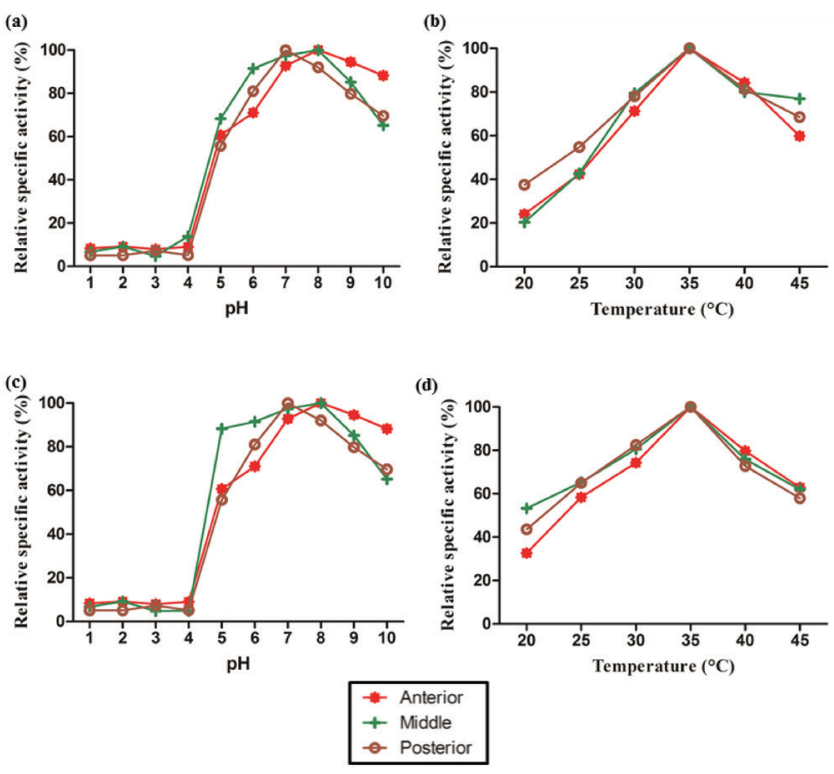

Figure 1. Effect of $\mathrm{pH}$ and temperature on the activity of amylase and protease of $L$. rohita. Fig. $1 \mathrm{a}$ and $1 \mathrm{~b}$ represent effect of $\mathrm{pH}$ and temperature on relative specific activity of digestive amylase respectively. Fig. $1 \mathrm{c}$ and $1 \mathrm{~d}$ represent effect of $\mathrm{pH}$ and temperature on relative activity of total protease, respectively. Enzyme activity was expressed as relative specific activity $(R S A)$. $R S A \%=\left(Z_{i} / Z_{\max }\right) \times 100\left[Z_{i}=\right.$ enzyme activity at specific $\mathrm{pH}$ or temperature value; $Z_{\max }=$ maximum enzyme activity]. In all cases, $\mathrm{n}=10$.

activity peaked the highest value was 3 in both stomach and pyloric caeca (Fig. 2a). In intestine, the highest activity of amylase was found at $\mathrm{pH}$ 8.0. Protease activity was at its peak in stomach at $\mathrm{pH}$ 2.0. In both pyloric caeca and intestine, $\mathrm{pH} 7.0$ was recorded as optimum value for highest activity (Fig. 2c). The optimum temperature for both amylase and protease activity were $35^{\circ} \mathrm{C}$ (Fig. 1b, 1d) throughout all regions of DT.

\section{Discussion and conclusions}

Biochemical studies of the digestive enzymes reflect the dietary specializations of the respective organism (Day et al. 2011). The present study aimed to study the ability to digest dietary carbohydrate and protein by two freshwater teleosts with different feeding habits and topologically dissimilar DTs. It also aimed to establish the optimum $\mathrm{pH}$ and temperature for the studied digestive enzymes along different parts of their DT. In the current study, the highest amylase activity was reported in the anterior DT for Rohu, and the activity was apparently twice than the mid and posterior DT. Here pancreatic amylase, which is found in association to hepatopancreas act as source of higher activity of amylase. It is known as the primary glucosidase available in fish (Candiotto et al. 2018). Fishes generally lack the salivary amylase prevalent 

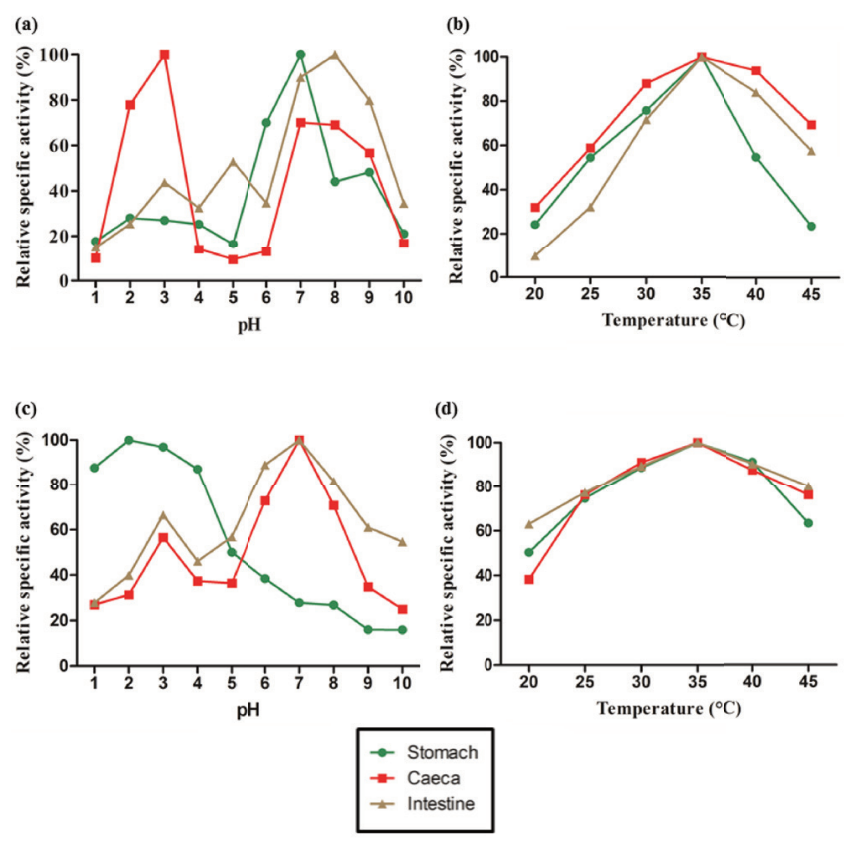

Figure 2. Effect of $\mathrm{pH}$ and temperature on the activity of amylase and protease of $A$. testudineus. Fig. $2 \mathrm{a}$ and $2 \mathrm{~b}$ represent effect of $\mathrm{pH}$ and temperature on relative specific activity of digestive amylase, respectively. Fig. $2 \mathrm{c}$ and $2 \mathrm{~d}$ represent effect of $\mathrm{pH}$ and temperature on relative activity of total protease, respectively. Enzyme activity was expressed as relative specific activity $(\mathrm{RSA}) . \mathrm{RSA} \%=\left(\mathrm{Z}_{\mathrm{i}} / \mathrm{Z}_{\max }\right) \times 100\left[\mathrm{Z}_{\mathrm{i}}=\right.$ enzyme activity at specific $\mathrm{pH}$ value; $Z_{\max }=$ maximum enzyme activity]. In all cases, $\mathrm{n}=10$.

in mammals, but intestinal $\alpha$-amylase is produced in the exocrine pancreas (Krogdahl et al. 2005). Day et al. (2011) found a similar pattern of amylase activity in Arrhamphus sclerolepi krefftii, which was again a stomachless herbivore fish. Similar result was observed by Parra et al. (2007) for $\alpha$-amylase in Pacific bluefin tuna Thunnus orientalis under culture conditions. Hidalgo et al. (1999) observed higher activity of amylase in omnivorous species Cyprinus carpio and found that amylase activity determined in the hepatopancreas of carp was high compared to digestive tract. It is known that amylase activity depends on the natural diet of fish species, and herbivorous and omnivorous fish have more amylase activity than carnivorous fish (Liu et al. 2016). Being an herbivore, Rohu has to consume a lot of plant materials rich in starch. Moreover, Ray et al. (2010) reported that Rohu has a sac like region (intestinal bulb) in the anterior portion of the DT, which is responsible for the temporary storage of the ingested food material. The requirement of high amylolytic activity in the anterior DT can be linked with the storage of plant based food at this region. Moderate amylolytic activity was enough for the breakdown of starch in the mid and anterior portion because the fish has a long DT. The longer the length of the DT the greater the chance of the action of digestive enzymes in herbivore fish and it may compensate the low specific activity of digestive enzyme. On the other hand, the results revealed that the pyloric caeca of Koi is the most active site for both $\alpha$-amylase and proteases. Similar result was reported in the study of Caruso et al. (2009), where the amylase and total protease activity in pyloric caeca of starved blackspot seabream (Pagellus bogaraveo) were potentially higher than the rest parts of the DT. The overall activity of amylase was higher in Rohu than Koi. This fact is in agreement with the popular principal that the amylase activity is always higher in the herbivorous fish species when compared to the carnivorous ones (Krogdahl et al. 2005).

The optimum $\mathrm{pH}$ for amylase activity in the Rohu was 8.0 for both the anterior and mid DT but at the posterior region of the DT, it was 7.0. However, in Koi the maximum activity of digestive amylase was obtained at $\mathrm{pH} 3.0$ in stomach in addition with some significant activity of digestive amylase was also found at the range of $\mathrm{pH} 7.0$ to $\mathrm{pH}$ 9.0. Subsequently the pyloric caeca and the intestine of Koi showed the optimum amylolytic activity at $\mathrm{pH} 8.0$, having a relatively weak tendency towards acidic amylase activity. Study of several authors (Parra et al. 2007; Xiong et al. 2011; Champasri and Champasri 2017) in different fish reveals that the general trend of digestive amylase activity picks at natural or alkaline $\mathrm{pH}$ in the intestine, and in stomach the amylase activity was slightly acidic (Munilla-Moran and Saborido-Rey 1996; Fernández et al. 2001; Xiong et al. 2011). Besides, diverse feeding habits of Koi may be one of the reasons of the activity observed within a wider range of $\mathrm{pH}$. The amylase activity has been reported within a wide range shows quite different feeding habits (Kawai and Ikeda 1971; Kuz'mina et al. 1996). Highest activity of amylase recorded at $35^{\circ} \mathrm{C}$ in all parts of the DT in both fish species. It is known that temperature ranging from $30^{\circ} \mathrm{C}$ to around $55^{\circ} \mathrm{C}$ was responsible for amylase activity in wild fish (Ugolev and Kuz'mina 1993; Parra et al. 2007; Xiong et al. 2011; Champasri and Champasri 2017; Candiotto 2018). But, in most cases, temperature of gut lumen in fish is closely linked to that of the environment as well as the water temperature and may have manifold effects on fish digestion (Munilla-Moran and Saborido-Rey 1996).

In the present study total proteolytic activity of both Rohu and Koi were measured. Study on proteolytic activity means the study of pepsin, trypsin, chymotrypsin, aminopeptidase, carboxypeptidase that, which act as a battery of enzymes (Torrissen 1987; Unajak et al. 2012). In Rohu, highest activity of protease was found in mid region of the DT followed by the posterior region. The lowest activity was found in the anterior DT. Day et al. (2011) made a similar observation in another stomachless fish Strongylura krefftii, where proteases were more 
active at mid and distal intestine than the proximal parts. However, in Koi the proteolytic activity of the stomach and the intestine showed no significant difference but for the stomach the optimum activity achieved at acidic $\mathrm{pH}$, whereas in the intestine the highest activity was taken place at the neutral $\mathrm{pH}$. Similar result was obtained in case of Glyptosternum maculatum, where protease activity was highest in stomach followed by anterior intestine (Xiong et al. 2011). In contrast to stomachless fish, proteolytic activity is highest in low $\mathrm{pH}$ condition when a stomach is present in fish (Kuz'mina 1990; Hidalgo et al. 1999).

On the other hand, the pyloric caeca in Koi exhibited maximum proteolytic activity at neutral $\mathrm{pH}(\mathrm{pH} 7.0)$ and in compared to stomach (highest activity at $\mathrm{pH}<2.0$ ), the proteolytic activity in intestine and pyloric ceaca were far higher at neutral $\mathrm{pH}$. Thus the proteolytic digestion in Koi takes place near neutral environment outside the stomach. In general, the maximum activity of protease at highly acidic $\mathrm{pH}$ in the stomach may be due to the stomach was bearing the gastric cells. Earlier, Lobel (1981) noted that the fish with a thin-walled stomach, with ability to considerably widen in the presence of large food items, the gastric $\mathrm{pH}$ was lower than in fish with a thick-walled stomach. Apparently, Koi maintains an ability to digest protein food in all the components across the gut with variable $\mathrm{pH}$. Such adjustment is often noticed in fishes with diversified food habits (Moyano et al. 2001). The optimum $\mathrm{pH}$ for total protease activity was 8.0 in both the anterior and mid region of the DT of Rohu, but the posterior portion showed optimum proteolytic activity at $\mathrm{pH}$ 7.0. It gives clear indication that neutral to alkaline range of $\mathrm{pH}$ has been the environment of gut in Rohu for protease digestion. The absence of stomach may be the probable reason why Rohu lacks acidic protease activity. These findings were similar with other findings where the optimum activity was close to $\mathrm{pH} 8.0$ (Hidalgo 1999; Pena et al. 2015; Aissaoui et al. 2017). All three regions showed some degree of acid protease activity at $\mathrm{pH} 5.0$ to $\mathrm{pH}$ 6.0. In the case of the current study, the maximum activity of protease was found to be at $35^{\circ} \mathrm{C}$ and it was somewhat in agreement with the study of Ugolev and Kuz'mina (1993), Munilla-Moran and Saborido-Rey (1996) and Aissaoui et al. (2017), where they showed the activity of proteases falls within a range of $35^{\circ} \mathrm{C}$ to $40{ }^{\circ} \mathrm{C}$ in various other fishes.

Although the observations here are compared for herbivorous versus omnivorous fish species and variable ranges of optimal activity of enzymes are presented under different $\mathrm{pH}$ as well as temperatures levels, it is to be kept in mind that there are different other factors, like time of ingestion of food, environmental temperature, emptiness of the stomach, food types available in the stomach for omnivorous, age of fish etc to effect the release of diges- tive enzymes at different frequencies throughout the gut (Solovyev et al. 2017). Nevertheless, it is also possible that the existence of more than one peak of optimal $\mathrm{pH}$ found in the above cases of Rohu and Koi indicates the possible existence of isoenzymes. Optimum $\mathrm{pH}$ and temperature for the enzyme activity varies along different regions of the DT (Fernández et al. 2001; Xiong et al. 2011; Solovyev et al. 2015) and within different fish (Fernández et al. 2001; Alarcón et al. 2001) as several isoforms may possibly present for a particular enzyme.

There is a strong relationship between the environment and the internal physiological state of fish, as it is an ectothermic aquatic organism. Concerning this relation, the internal physiological environment of the fish also modulated or affected by the environmental conditions. Various seasons are with various temperatures and as a rule of thumb, $\mathrm{pH}$ decreases with an increase in temperature. So, the self-adjustment of the ectothermic aquatic animal obviously affects its gastrointestinal digestive purpose accordingly (Solovyev and Izvekova 2016). Our study mainly conveyed the unique pattern of the complete activity of amylase and protease from different positions along with the DT of $L$. rohita and A. testudineus across a series of $\mathrm{pH}$ and temperature values. We established the specific distribution of major digestive enzymes working in various digestive sections in the studied fish species. The study also demonstrated typical patterns of varying activity depending on location in the digestive tract, $\mathrm{pH}$ and temperature. It is the primary study of the digestive physiology of L. rohita and A. testudineus, and further research should be carried out to learn greater details regarding its digestion and nutrition. In this context, this study surely going to guide the researchers who are working with the diet preparation or feed formulation of the studied fish species.

\section{Acknowledgments}

This work was supported by the Council of Science \& Industrial Research (CSIR), India. Authors also acknowledge the facility supported under the programmes DSTFIST and CAS (UGC) in the Department of Zoology, and DST-PURSE in Siksha Bhavana, Visva-Bharati, West Bengal, India.

\section{References}

Aissaoui N, Marzouki MN, Abidi F (2017) Purification and biochemical characterization of a novel intestinal protease from Scorpaena notata. Int J Food Prop 20:2151-2165. 
Banerjee G, Ray AK (2018) The effect of seasonal temperature on endogenous gut enzyme activity in four air-breathing fish species. Croat J Fish 76:60-65.

Bernfeld P (1955) Amylases alpha and beta. In Colowick S, Kaplan N, Eds., Methods in Enzymology I. Academic Press, New York. 149-158.

Bogard JR, Thilsted SH, Marks GC, Wahab MA, Hossain MA, Jakobsen J, Stangoulis J (2015) Nutrient composition of important fish species in Bangladesh and potential contribution to recommended nutrient intakes. J Food Compost Anal 42:120-133.

Candiotto FB, Freitas-Júnior AC, Neri RC, Bezerra RS, Rodrigues RV, Sampaio LA, Tesser MB (2018) Characterization of digestive enzymes from captive Brazilian flounder Paralichthys orbignyanus. Braz J Biol 78:281-288.

Caruso G, G Denaro M, Genovese L (2009) Digestive enzymes in some teleost species of interest for Mediterranean aquaculture. Open Fish Sci J 2:74-86.

Champasri C, Champasri T (2017) Biochemical characterization, activity comparison and isoenzyme analysis of amylase and alkaline proteases in seven cyprinid fishes. J Fish Aquat Sci 12:264-272.

Day RD, German DP, Tibbetts IR (2011) Why can't young fish eat plants? Neither digestive enzymes nor gut development preclude herbivory in the young of a stomachless marine herbivorous fish. Comp Biochem Physiol B 158:23-29.

de la Parra AM, Rosas A, Lazo JP, Viana MT (2007) Partial characterization of the digestive enzymes of Pacific bluefin tuna Thunnus orientalis under culture conditions. Fish Physiol Biochem 33:223-231.

Fernández I, Moyano FJ, Díaz M, Martínez T (2001) Characterization of $\alpha$-amylase activity in five species of Mediterranean sparid fishes (Sparidae, Teleostei).J Exp Mar Biol Ecol 262:1-12.

Hidalgo MC, Urea E, Sanz A (1999) Comparative study of digestive enzymes in fish with different nutritional habits. Proteolytic and amylase activities. Aquaculture 170:267-283

Hsu YL, Wu JL (1979) Relationship between feeding-habits and digestive proteases of some freshwater-fishes. Bull Inst Zool Acad Sin 18:45-53.

Izvekova GI, Solovyev MM (2012) Activity of digestive hydrolases in fishes infected with cestodes. Usp Sovrem Biol 132:601-610.

Kawai SI, Ikeda S (1971) Studies on digestive enzymes of fishes. I. Carbohydrases in digestive organs of several fishes. Bull Japan Soc Sci Fish 37:333-337.

Kofuji PY, Akimoto A, Hosokawa H, Masumoto T (2005) Seasonal changes in proteolytic enzymes of yellowtail Seriola quinqueradiata (Temminck \& Schlegel; Carangidae) fed extruded diets containing different protein and energy levels. Aquac Res 36:696-703.
Kole D, Mondal S, Ghosh AR (2018) Effects of arsenic (III) and chromium (VI) toxicity on digestive enzymes' activities of Anabas testudineus (Bloch)Proc Zool Soc 71:178-185

Krogdahl Å, Hemre GI, Mommsen TP (2005) Carbohydrates in fish nutrition: digestion and absorption in postlarval stages. Aquac Nutr 11:103-122.

Krogdahl A, Hemre GI, Mommsen TP (2005) Carbohydrates in fish nutrition: digestion and absorption in postlarval stages. Aquac Nutr 11:103-122.

Kuz'mina VV (1990) Temperature influence on the total level of proteolytic activity in the digestive tract of some species of freshwater fishes. J Ichthyol 30:97-100.

Kuz'mina VV (1996) Influence of age on digestive enzyme activity in some freshwater teleosts. Aquaculture 148:25-37.

Kuz'mina VV, Strel'nikova AP (2008) Influence of diurnal rhythms of feeding during intestine total amylolytic activity and activity of alkaline phosphatase in juvenile fish. Inland Water Biol 1:182-191.

Liu H, Guo X, Gooneratne R, Lai R, Zeng C, Zhan F, Wang W (2016) The gut microbiome and degradation enzyme activity of wild freshwater fishes influenced by their trophic levels. Sci Rep 13:24340.

Lobel PS (1981) Trophic biology of herbivorous reef fishes: alimentary $\mathrm{pH}$ and digestive capabilities. J Fish Biol 19:365-397.

Lowry OH, Rosebrough NJ. Farr AL, Randall RJ (1951) Protein measurement with the Folin phenol reagent. J Biol Chem 193:265-275.

Majumder S, Saikia SK (2020) Ecological intensification for feeding rohu Labeo rohita (Hamilton, 1822): A review and proposed steps towards an efficient resource fishery. Aquac Res 51(1):3072-3078.

Mandal S, Ghosh K (2010) Inhibitory effect of Pistia tannin on digestive enzymes of Indian major carps: an in vitro study. Fish Physiol Biochem 36:1171-1180.

Mohanty BP, Sankar TV, Ganguly S, Mahanty A, Anandan R, Chakraborty K, Paul BN, Sarma D, Dayal JS, Mathew S, Asha KK (2016) Micronutrient composition of 35 food fishes from India and their significance in human nutrition. Biol Trace Elem Res 174:448-458.

Moyano FJ, Savoie L (2001) Comparison of in vitro systems of protein digestion using either mammal or fish proteolytic enzymes. Comp Biochem Physiol A 128:359-368.

Munilla-Morán R, Saborido-Rey F (1996) Digestive enzymes in marine species. II. Amylase activities in gut from seabream (Sparus aurata), turbot (Scophthalmus maximus) and redfish (Sebastes mentella). Comp Biochem Physiol B 113:827-834.

Munshi M, Tumu KN, Hasan MN, Amin MZ (2018) Biochemical effects of commercial feedstuffs on the fry of climbing perch (Anabas testudineus) and its impact on Swiss albino mice as an animal model. Toxicol Rep 5:521-530. 
Paul BN, Chanda S, Bhowmick S, Sridhar N, Saha GS, Giri SS (2017) Nutrient profile of Indian climbing perch, Anabas testudineus. SAARC J Agric 15:99-109.

Peña E, Hernández C, Álvarez-González CA, Ibarra-Castro L, Puello-Cruz A, Hardy RW (2015) Comparative characterization of protease activity in cultured spotted rose snapper juveniles (Lutjanus guttatus). Lat Am J Aquat Res 43:641-650.

Ray AK, Roy T, Mondal S, Ringø E (2010) Identification of gut-associated amylase, cellulase and protease-producing bacteria in three species of Indian major carps. Aquac Res 41:1462-1469.

Samanta P, Pal S, Mukherjee AK, Senapati T, Ghosh AR (2014) Effects of almix herbicide on metabolic enzymes in different tissues of three teleostean fishes Anabas testudineus, Heteropneustes fossilis and Oreochromis niloticus. Int J Sci Res Env Sci 2:156-163.

Singh G, Bhatnagar A, Alok K, Ajay SA (2018) Enzymatic profiling and feeding preferences of Catla: Catla catla, Rohu: Labeo rohita and Mrigala: Cirrhinus mrigala in rural polyculture ponds. J Aquac Res Dev 9:1-8.

Solovyev MM, Izvekova GI (2016) Seasonal changes in pH values in the intestine of fish from Lake Chany (West Siberia). Inland Water Biol 9:400-404.

Solovyev MM, Kashinskaya EN, Izvekova GI, Glupov VV (2015) $\mathrm{pH}$ values and activity of digestive enzymes in the gastrointestinal tract of fish in Lake Chany (West Siberia). J Ichthyol 55:251-258.

Talwar PK, Jhingran AG (1991) Inland Fisheries of India and Adjacent Countries. Vol. I. Oxford and IBH Publishing,
New Delhi, India.

Torrissen KR (1987) Genetic variation of trypsin-like isozymes correlated to fish size of Atlantic salmon (Salmo salar). Aquaculture 62:1-10.

Uddin KB, Moniruzzaman M, Bashar MA, Basak S, Islam AS, Mahmud Y, Lee S, Bai SC (2016) Culture potential of Thai climbing perch (Anabas testudineus) in experimental cages at different stocking densities in Kaptai Lake, Bangladesh. Aquac Aquar Conserv Legis 9:564-573.

Ugolev AM, Kuz'mina VV (1993) Digestive Processes and Adaptations in Fish. St. Petersburg: Gidrometeoizdat.

Unajak S, Meesawat P, Paemanee A, Areechon N, Engkagul A, Kovitvadhi U, Kovitvadhi S, Rungruangsak-Torrissen K, Choowongkomon K (2012) Characterisation of thermostable trypsin and determination of trypsin isozymes from intestine of Nile tilapia (Oreochromis niloticus L.). Food Chem 134:1533-1541.

Walter HE (1984) Proteinases: methods with haemoglobin, casein and azocoll as substrates. In Bergmeyer HU, Bergmeyer J, GraBl M. Methods of Enzymatic Analysis, Vol 5, 3rd Ed., Verlag Chemie, Weinheim, Germany, 270-277.

Weinrauch AM, Schaefer CM, Goss GG (2019) Activity and post-prandial regulation of digestive enzyme activity along the Pacific hagfish (Eptatretus stoutii) alimentary canal. PLOS ONE 14:e0215027.

Xiong DM, Xie CX, Zhang HJ, Liu HP (2011) Digestive enzymes along digestive tract of a carnivorous fish Glyptosternum maculatum (Sisoridae, Siluriformes). J Anim Physiol An Nutr 95:56-64. 
